No.5 p 13-16

\title{
Problems in Tourist Regionalization of Danube Basin Area in Vojvodina
}

Romelić, J., Tomić, P. *

\begin{abstract}
The paper is concerned with the question whether the part of Danube Basin running through Vojvodina, as a clearly defined geographic entity, represents a unique tourist region. Our research, as well as the research of other authors, has shown that the area next to the Danube Basin contains tourist attractions and utilities distributed in such a way that they partly overlap with certain parts of the Danube Basin. This sort of tourist physiognomy of Vojvodina's Danube Basin and adjoining areas, as well as the way in which they intertwine, has influenced our decision to set apart three tourist regions: Sombor-Apatin, Novi Sad-Fruska Gora and Vrsac-Danube Basin. They show high tourist individuality compared to the Danube Basin area as a whole, and yet each of them spreads over one particular part of that area. The paper also gives explanations of the above opinions.
\end{abstract}

Key words Danube Basin area, tourist regions, tourist values, statistical indices

* Jovan Romelić, Pavle Tomić, University in Novi Sad, Faculty of Natural Sciences, Institute of Geography, Tourismology and Hotel Management, Trg Dositeja Obradovića 3, 21000 Novi Sad, Yugoslavia
$\mathrm{V}$ ojvodina's part of Danube Basin area includes the Danube river running through Vojvodina and the area around the river. From the administrative point of view, this territory includes the following municipalities: Sombor, Apatin, Odžaci, Bač, Bačka Palanka, Bački Petrovac, Novi Sad, Titel, Beočin, Sremski Karlovci, Inđija, Stara Pazova, Pančevo, Kovin and Bela Crkva.

The total surface of this area is 6812.5 $\mathrm{km}^{2}$. According to the 1991 census, there are 851122 inhabitants living in the area. The area takes up $31.6 \%$ of the territory and $42.3 \%$ of the population of Vojvodina (125 inhabitants per $\mathrm{km}^{2}$ ). This fact clearly shows that the Danube Basin area has got good basis for development and, therefore, dense population, relatively high urbanization and dynamic economy.

However, the concentration of tourist resources in this area is not even. Their density gradually becomes lower as one moves away from the river. However, if we consider the areas bordering the area of Danube Basin, we can see that some of them contain important tourist attractions, like: Fruš ka Gora, the Vrsac Mountain and the Banat Sands. They could be included in the tourist and geographic physiognomy of the Danube Basin region, which would be an improvement for its tourist offer.

Intensive daily and weekend tourist circulation is characteristic for Vojvodina's Danube Basin area. This can be explained by the density of sites suitable for recreation, as well as by the mobility of the population living in the towns of the Danube Basin area (Novi Sad, Bačka Palanka, Sombor, Pančevo, Inđija, Beočin, Sremski Karlovci, Apatin, Bela Crkva, etc). In addition to this, all the centers of tourist emission which are located on an one-day distance from the Danube Basin play an important role in the tourist demand.

Considering specific characteristics of natural tourist potentials, the various forms of tourism that we can expect to develop in this area are: nautical, recreational, sport, hunting, fishing, selective, etc.

Among the anthropological tourist resources, we should mention numerous tourist manifestations, many of which are international. The most prominent ones are of sport or economic character, which attract the largest number of participants and visitors from abroad. Vojvodina's folklore tradition is another factor which has the attributes of tourist attractiveness. It should be included in the tourist offer by creative presentation. Considering cultural and historical values of this area, the most prominent sites are, of course, the numerous monasteries in Fruška Gora, Middle Age fortresses and old cities. The old city centers, with their varied architecture, represent sites of specific milieu, which can play a functional role in, so called, city tourism.

\section{General Tourist and Geographic Characteristics of the Danube Basin Area}

The Vojvodina's part of Danube Basin area is divided among three tourist regions in the province: Sombor-Apatin region, Novi Sad-Fruška Gora region and Vršac-Danube Basin region. The borders of the Vojvodina's part of Danube Basin area are defined by the outside borders of those municipalities that the Danube runs through. The tourist regions mentioned above spread over the Danube Basin area in such a way that the Sombor-Apatin region belongs to it entirely, while the other two spread beyond it. The tourist region Vršac-Danube Basin overlaps with the Danube Basin area in the municipalities Kovin and Bela Crkva, whereas the Vršac municipality itself is found beyond the Danube Basin area. The tourist region Novi Sad-Fruska Gora overlaps with the Danube Basin area in the following municipalities: Novi Sad, Bačka Palanka, Titel, Beočin, Sremski Karlovci and Inđija. The municipalities of Irig, Šid and Ruma are beyond the Danube Basin area and they belong to the tourist subregion of Fruška Gora.

Although the Danube Basin area as a whole has a more prominent geographic physiognomy than any of the three tourist regions mentioned above, most authors do not recognize it as a separate tourist region. The present regionalization is a result of rigorous criteria in the Spatial Plan of Serbia made in 1995 and the research done by some authors in 


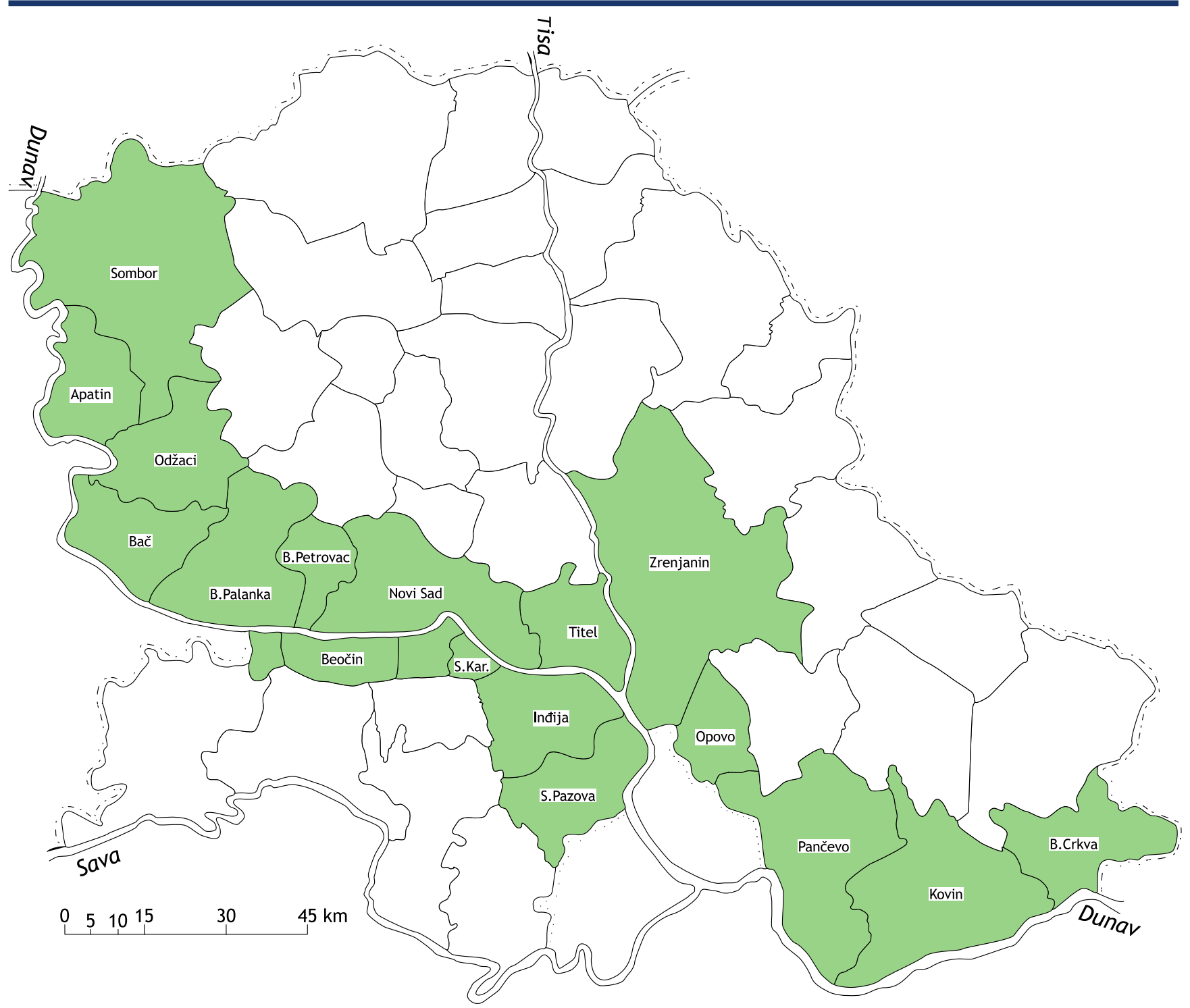

Figure 1. Propagation of Danube Area in Vojoodina Part

1997, Čomic and Pjevač being the most precise among them.

Objects, features and processes within each of the region can gradually transform, disappear or pass into the adjoining region. Therefore, the borders are sometimes hard to define with precision, except when defined by a relief or geographic features like Fruška Gora, Banat Sands or Vršac Mountain. In these areas, the borders of tourist values and activities are obvious.

\section{The Problem of Borders Between the Danube Basin Area and Present Tourist Regions}

If we want to clear the dilemma whether Vojvodina's Danube Basin area represents a unique and independent region or whether it must be divided among the present tourist regions in Vojvodina, we should first give an answer to the following question: which geographic objects, features and processes, relevant for tourism, are common for the whole

\section{Danube Basin area?}

Primarily, there is the river Danube, which has formed the terrain typical for plain rivers, thanks to its erosive and accumulative activities. This terrain has specific morphologic, hydrographic, biogeographic and pedologic features. Although the mentioned factors have had their share in forming the river, it was the river that later took the dominant role in the process of genesis of its environment. It has influenced the general geographic physiognomy of the area including objects and features which have certain attractive attributes - esthetic, recreational, historical, etc. The river and its valley have largely contributed to intensive population, economic activities and the creation of a relatively tight network of settlements. These are the spatial units which emanate tourists looking for recreation and cultural relaxation.

The attractions mentioned above and certain forms of tourism are the common elements for the Danube Basin. On the other hand, there are some elements which cannot be found all the way along the river. They are scattered or they appear as a curiosity of certain area near the river Danube.

If we were to adopt the above mentioned tourist regionalization, that would mean that the Danube Basin area does not have a character of tourist macro-region. The main reason is that the three tourist regions spread beyond the borders of Danube Basin. This area is full of details taking the shape of tourist attractiveness, reception, communicational, infrastructural and suprastructural objects. All of them need careful valorization, reconstruction and precise planning, which can be achieved only within certain regions, since they offer more possibilities for satisfying different tourist demands than the others.

The big advantage of the Danube Basin is its geographic location, characterized by the Danube river and important roads lying along it. From the more general point of view, all these regions, including Danube Basin area, belong to the East European tourist region. In addition, all three regions and the Danube Basin area have strong centers of 


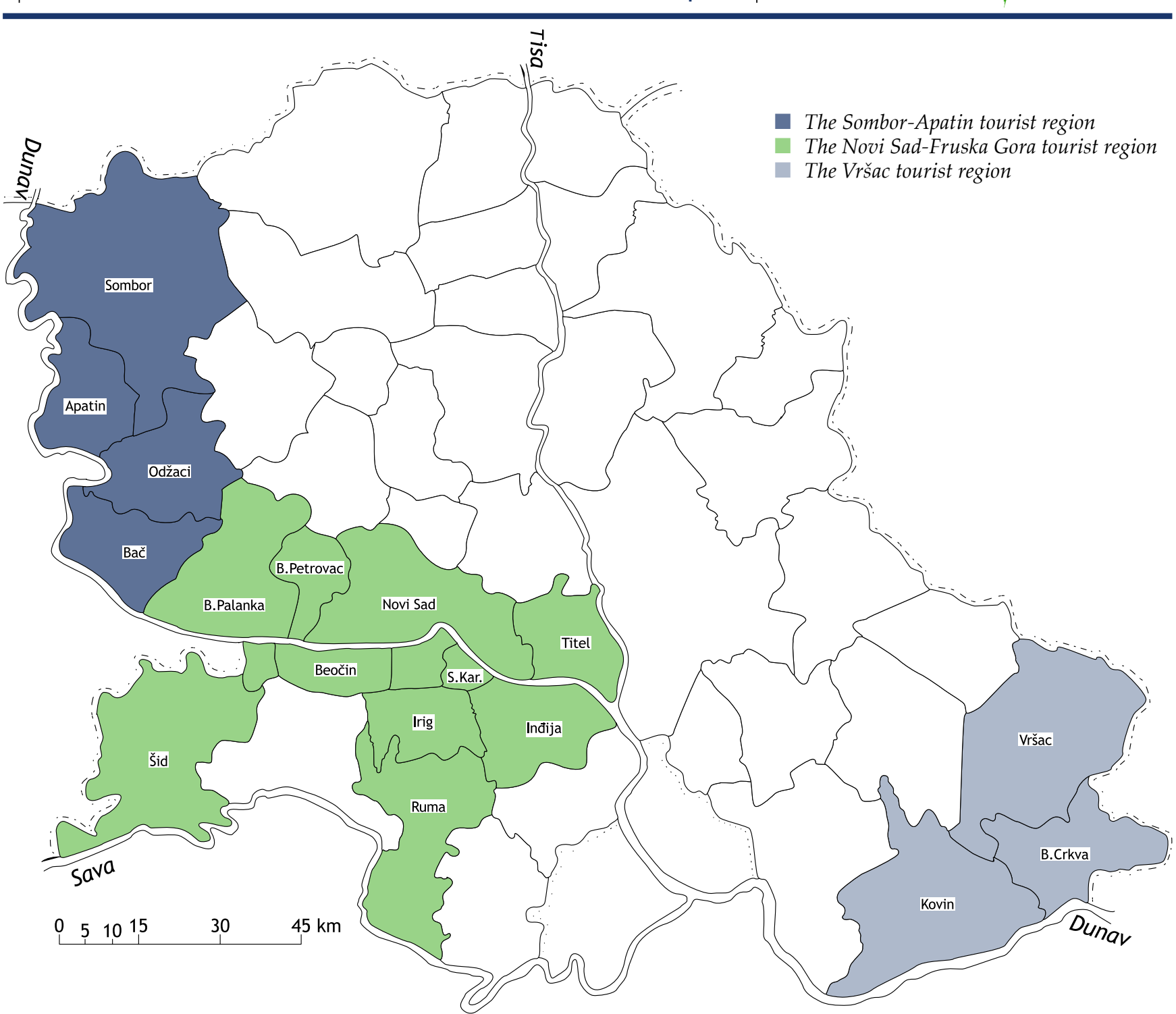

Figure 2. Danube Area of Vojvodina Part and Tourism Regions

tourist emission. The local population shows firm habit of tourist movements. In the summer, for example, the recreation localities with swimming facilities are crowded by people from the local contraction zone.

Tourist regions which border on each other, and form an integral part of the Danube Basin area, are also different from each other regarding the level of activation of tourist values. Tourist values of the Novi Sad-Fruška Gora region are highly activated, while, in the VršacDanube Basin region, the activation of tourist values is not particularly high, except for the lake near Bela Crkva. Similarly, the Sombor-Apatin region has many potential values, which still do not have their full application in tourism.

Our hypothesis is that the border zones will gradually join one of the tourist regions or they will be formed as separate taxonomic units with tourist function, since they have some tourist resources themselves. Thus, the whole Danube Basin Region, and not only the Vojvodina's part, will probably repre- sent a unique well-known tourist region. The individual features of the present tourist regions will survive, but they will not be as obvious as today.

\section{Tourist Features of the Regions Which Overlap With Vojvodina's \\ Danube Basin}

Present tourist regions have the character of heterogenous area in which tourism plays a side role in the economic activities. This is, primarily, the outcome of their position of unknown and, therefore, only potential tourist regions.

The Sombor-Apatin tourist region extends from Bačka Palanka to Hungarian border, including canals and swamps, hunting grounds, the Junaković Spa and the towns of Sombor, Apatin and Bezdan. (Čomic, Pjevač, 1997) This region is characterized by hydrographic features created in the process of meandering i.e. moving of the Danube's riverbed. There fore, there is a big number of meanders, stagnant tributaries and sand is- lands. Hydrographic resources include: Bajski canal, Barački Dunavac, Monoštorski Dunavac, Kupisinski Dunavac, Petreški Dunavac and Srebrnički Dunavac.

Other specific features are represented by numerous sand accesses to the river which can be used as beaches. They are still in their natural state, which is their advantage, according to Stojanovic $(2000,118)$, because "it intensifies the effect of autochthonous landscape".

This region is the location of the Junakovic Spa valuable for its thermo-mineral waters, which is typical of most Vojvodina's spas.

The region is characterized by exceptional ecosystem values. Its meadows and swamps, as well as its priceless geo-inheritance have been the reason for proclaiming this area a natural park called "Upper Danube Basin". In the future, it will be promoted into Special nature reserve, as a part of MAV project, which also includes the ecosystems of the rivers Mura, Drava and Danube. (Stojanović, 2000,119) 
Big stock of wild animals in this area is a good basis for development of hunting tourism in the hunting grounds of Apatin swamp and Kozara (near Backi Monostor). The area is even more attractive due to the presence of 267 bird species, which is a precondition for the development of bird watching tourism. The cultural and historical inheritance is concentrated mainly in Sombor and Apatin.

The Novi Sad-Fruška Gora tourist region includes the city of Novi Sad, a big tourist and urban center, the Fruška Gora mountain, a potential tourist center of the region, and the Danube river, from Bačka Palanka to the mouth of the Tisa river (together with Bačka Palanka and Irig). The Tikvara lake is located near Bačka Palanka. It was valorized and, as a result, a sport and recreation center was built at the lake. The part of the Danube river from Bačka Palanka to Novi Sad is rich with sand islands (ada): Šarengradska ada, Govneš ada, Neštinska ada, the Velika ada, Čerevićka ada, Šešićeva ada, etc. They do not have a tourist function, but they could be used for the development of controlled recreational activities. On the banks of Novi Sad, there are several beaches - among which Štrand is the biggest - and the well-known recreation locality "Ribarsko ostrvo".

An attractive hydrographic object in this region is the Kovilj swamp, one of the Danube rukavac. This complex includes numerous canals, stagnant tributaries and ponds, which are surrounded by rich flora and fauna. The swamp has a status of Special nature reserve, but it also serves as a nature reserve for science research.

The hunting tourism is quite developed, especially in the hunting ground Karađorđevo. In addition to hunting, the locality offers fishing, photo-safari, visiting horse stables and sightseeing on charriots and boats.

City tourism is mainly connected with Novi Sad and includes various forms of tourism, based on the different functions of the city itself: economic, administrative, cultural, etc.

The main characteristic of this region, which sets it apart from all the others, is the Fruska Gora mountain. It is the ideal place for sport and recreation, as well as various cultural manifestations. In addition, the whole mountain represents a national park with many possibilities for the development of selective tourism.

The Vrsac-Danube Basin tourist region includes one part of the Banat Sands, the Vršac mountain, the rivers Karaš and Nera, a part of the Danube river, the border crossing Vatin and the towns of Vršac and Bela Crkva. This is a unique region: the alluvial plane along the Danube here is not as attractive as in other parts of the river; however, the region includes the Lakes of Bela Crkva which represent a unique and well-known tourist complex. Another attractive locality is the Banat Sands, which offers many possibilities for the development of selective tourism.

Beyond the Danube Basin area, this region includes the Vrsac mountain - a locality whose functions aim towards sport and recreational tourism.

\section{Conclusion}

Tourist regions which border on each other, and form an integral part of the Danube Basin area, are also different from each other regarding the level of activation of tourist values. Tourist values of the Novi Sad-Fruška Gora region are highly activated, while, in the VršacDanube Basin region, the activation of tourist values is not particularly high, except for the lake near Bela Crkva. Similarly, the Sombor-Apatin region has many potential values, which still do not have their full application in tourism.

The Danube Basin area does not have a character of tourist macro-region. The main reason is that the three tourist re- gions spread beyond the borders of Danube Basin. This area is full of details taking the shape of tourist attractiveness, reception, communicational, infrastructural and suprastructural objects. All of them need careful valorization, reconstruction and precise planning, which can be achieved only within certain regions, since they offer more possibilities for satisfying different tourist demands than the others.

\section{References}

Büschenfeld, H. (1999): Wirtschaftliche Transformationprocesse in der nachfolgestaaten Jugoslawiens, Europa Regionaln, Nummer 4, Institut für Länderkunde, Leipzig, Seite 23-38.

Čomić, Đ., Pjevač, N. (1997): Turistička geografija, Savezni centar za unapređenje ugostteljstva i hotelijstva, Beograd.

Jovanović, G. (2000): Turistički potencijali vojvođanskog Podunavlja i mogućnoti njegove valorizacije, Prirodno-matematički fakultet, Institut za geografiju, Novi Sad.

Romelić, J., Tomić, P. (2000): Udeo turizma i ugostiteljstva u privredi Vojvodine, Turizam, broj 4, Savremene tendencije u turizmu 2000, Prirodnomatematički fakultet, Institut za geografiju, Novi Sad, strana 24-29.

Romelić, J., Ćurčić, N. (2001): Turistička geografija Jugoslavije, Prirodnomatematički fakultet, Institut za geografiju, Novi Sad, strana 1-252.

Statistički pregled po opštinama Srbije, Republički zavod za statistiku, Beograd, 1980-2000.

Stojanović, V. (2000): Turistički potencijali Podunavlja u Bačkoj, Zbornik instituta za geografiju, Prirodnomatematički fakultet, Institut za geografiju, Novi Sad, strana 116-130.

Winkler, P. (1999): Indikatoren zur Efassung regionaler Problemlagen, Österraichisches Institut für Raumplanung, Wien. 